\title{
Fallow deer (Dama dama dama) management in Roman South-East Britain
}

Richard Madgwick, Cardiff University, School of History, Archaeology and Religion, Humanities Building, Colum Drive, Cardiff, CF10 3EU, UK

Naomi Sykes, Department of Archaeology, University of Nottingham, Humanities Building, University Park, Nottingham, NG7 2RD, UK

Holly Miller, Department of Archaeology, University of Nottingham, Humanities Building, University Park, Nottingham, NG7 2RD, UK

Rob Symmons, Fishbourne Roman Palace, Roman Way, Fishbourne, West Sussex, PO19 3QR, UK

James Morris, Department of Archaeology, University of Central Lancashire, Preston, Lancashire, PR1 $2 H E, U K$

Angela Lamb, NERC Isotope Geosciences Laboratory, Kingsley Dunham Centre, British Geological Survey, Keyworth, Nottingham, NG12 5GG, UK

*corresponding author email: madgwickrd@cardiff.ac.uk, tel: +44 (0)2920 870403

\section{Abstract}

This paper presents new carbon, nitrogen and sulphur isotope data for European fallow deer (Dama dama dama) in Roman Britain and discusses results in light of evidence from classical texts, landscape archaeology, zooarchaeology and the limited available samples of metric data. The new isotope data presented here are from Fishbourne Roman Palace (Sussex), two sites on the Isle of Thanet (Kent) and a further two sites in London. In spite of small sample sizes the data make an important contribution to the very limited corpus of scientific research on the species and provide new resolution to the nature of fallow deer movement and management in Roman Britain.

Keywords: fallow deer, stable isotopes, Roman Britain, biogeography, management

\section{Introduction}

Until recently, the European fallow deer (Dama dama dama) had been subject to little archaeological research and consequently the timing and character of this species' diffusion from its Last Glacial Maximum refugium in Turkey remained poorly understood. The last decade has seen a steady increase in research dedicated to fallow deer (e.g. Davies and MacKinnon 2009; Langbein and Chapman 2003; Massetti 2002; Massetti et al. 2006; Sykes 2004, 2007, 2010; Sykes et al. 2006, 2010, in press; Sykes and Carden 2011) and this paper is the first from a new research project that aims to increase knowledge of the species' natural and cultural history.

Reconstructing the biogeography and management of fallow deer in Britain has proved difficult, complicated by problems of misidentification and inadequate dating (see Sykes 2004; 2010). Originally the introduction of fallow deer was attributed to the Romans (Lever 1977; Millais 1906; Whitehead 1972) but latterly the Normans became more popular candidates for their importation (e.g. Langbein and Chapman 2003; Sykes 2004; Yalden 1999). In recent years, however, the case for a Roman introduction has been resuscitated by new finds of dama remains on an increasing number 
of Romano-British sites. The majority come from sites located in southern England (see Sykes et al. 2006) but examples have been reported as far north as Binchester, County Durham, in the north east (Petts pers. comm.).

Whilst these finds would appear to confirm the presence of fallow deer in Roman England, they cannot be accepted uncritically: in antiquity there was a lively trade in fallow deer antlers and metapodia, and the representation of these skeletal elements need not be seen as evidence for established breeding populations (Sykes 2010). Interestingly it is precisely these elements - shed antlers and foot bones - that make up the bulk of specimens reported for Romano-British sites. For instance, shed antlers are present, with no other associated fallow deer bones at St. Albans in Hertfordshire, Scole Dickleburgh in Norfolk, and Dorchester-on-Thames in Oxfordshire (see references in Sykes et al. 2011). The reasons for this trade could be for craft working (Sykes 2004) but Roman texts intimate that they were more probably traded for their medicinal properties: according to Pliny the Elder's Natural History powered deer antlers could be used to cure a range of disorders, from tooth ache to epilepsy (see book XXVII, trans. Jones 1963).

For the whole of Roman Britain, only two sites have produced securely dated assemblages with more than five fallow deer specimens and a balanced pattern of skeletal element representation: Monkton on the Isle of Thanet in Kent $(n=9)$ and Fishbourne in Sussex $(n=38)$. In relation to Fishbourne, Sykes et al.'s (2006) integrated programme of AMS dating and strontium isotope analysis identified early introductions to the site, with mandibles dated to $60 \mathrm{AD} \pm 40$ and $90 \mathrm{AD} \pm 40$. The Sr isotope results provided convincing evidence that the earlier of the two mandibles was from a first generation introduction: the Sr ratio for the first molar demonstrated an allochthonous origin during early development, whereas the signature from the third molar indicated that the same individual was likely to have been in the Fishbourne area during sub-adulthood.

The integration of different analytical approaches was also undertaken for the Monkton material, with a combination of osteometrics, aDNA, AMS radiocarbon dating and stable isotopes $\left(\delta^{13} \mathrm{C}\right.$ and $\delta^{15} \mathrm{~N}$ ) employed (Sykes et al. 2011). Although interpretations were hindered by a lack of comparative data, radiocarbon results indicated that the Monkton deer are later than those from Fishbourne $\left(2^{\text {nd }}\right.$ and $3^{\text {rd }}$ century $\left.A D\right)$. Osteometric analyses, which demonstrated that the Monkton deer were rather small in size, suggest that they most probably derived from translocated populations, rather than Anatolia or Greece where body size is larger (Sykes et al. 2011). Genetic data appeared to confirm this suggestion, the aDNA data mapping more closely with modern Italian deer than Anatolian populations (Sykes et al. 2011).

Together, the Fishbourne and Monkton assemblages provide strong evidence that fallow deer were, indeed, first introduced to England during the Roman period. Despite this advance, the mechanisms by which this exotic species was managed and moved in life and death remain poorly understood. As part of a broader project that aims to integrate archaeology, history, geography and anthropology with genetics, stable isotope analysis and osteological research to examine the circumstances and cultural significance of fallow deer diffusion across Europe, this paper presents preliminary stable isotope data $\left(\delta^{13} \mathrm{C}, \delta^{15} \mathrm{~N}\right.$ and $\left.\delta^{34} \mathrm{~S}\right)$ that sheds some light on aspects of the management of this underresearched species. This study examines the potential of stable isotope data to provide evidence for 
early breeding populations, the large-scale movement of live animals and the trade of elements such as antler.

Most of the data presented here relate to the substantial samples of fallow deer from Fishbourne and Monkton. In addition, small samples of data are presented from two newly excavated sites close to Monkton on the Isle of Thanet - the East Kent Access Road $(n=2)$ and Tothill Street, Minster $(n=3)$ - and two specimens from Roman London (London Bridge, $n=1$; Arcadia Buildings, $n=1$ ): See Figure 1 for locations. Summary statistics for two sets of results from a growing dataset of international samples are also presented. These results, from Anatolia and Mallorca, provide important background information on which more cogent interpretations can be built and will be explored further in future publications. Where possible, the British results are tentatively integrated with other sources of evidence to further advance our understanding of the species in Roman England until more data is available for more robust interpretation.

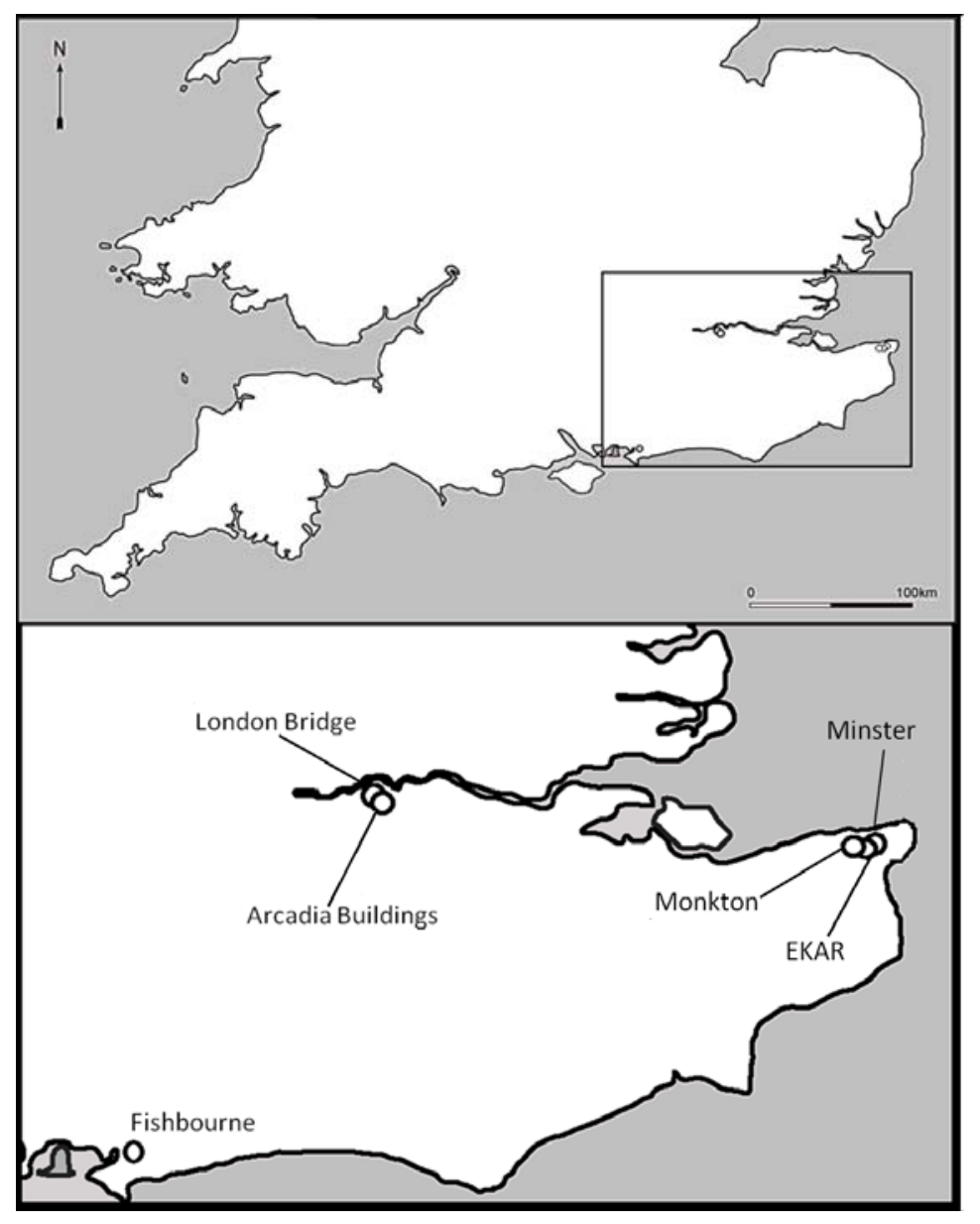

Fig. 1 Map showing the locations of sampled sites in south east England

\section{Materials and Methods}

\section{Samples}

Due to the scarcity of Romano-British fallow deer bones, an inclusive sampling strategy was employed. All $D$. $d$. dama specimens that could be confidently identified as Roman (based on 
stratigraphy or associated material) were sampled, except for those of a pre-weaned age, as such individuals effectively feed at a higher trophic level. Age determination was based on epiphyseal fusion; dental attrition and cortical development and only samples that were judged to be from individuals of at least sub-adult age were selected (Carden and Hayden 2006). Samples include bone, dentine and antler and therefore range from tissues with a rapid turnover rate to those which do not remodel after development. The small number of available samples meant that no attempts could be made to select repeat zones of the same sided element, as has been employed in some studies (e.g. Madgwick et al. 2012). Therefore it is possible that some samples may derive from the same individual.

\section{The Sites}

Sites for which new carbon and nitrogen isotope data are presented are briefly described below. As data from Monkton has been published elsewhere (Sykes et al. 2011) the site is not described here.

\section{Fishbourne, Sussex}

Fishbourne Roman Palace was a high-status Romano-British residence and has been subject to two major excavation campaigns (Cunliffe 1971a, 1971b; Manley and Rudkin 2005). The palace was built in the first century $A D$ and was subsequently redeveloped in the $2^{\text {nd }}$ and $3^{\text {rd }}$ centuries (Cunliffe 1998), after which it was abandoned. Excavations yielded a large faunal assemblage dominated by domestic taxa (Grant 1971), with fallow deer being identified during re-analysis. Isotope data are presented for 34 specimens, as 4 additional samples failed to yield sufficiently preserved collagen (see DeNiro 1985).

The East Kent Access Road (EKAR), Isle of Thanet, Kent

The East Kent Access Road project was undertaken by Oxford Wessex Archaeology between 2009 and 2011. Excavations revealed wide-ranging evidence for multi-period occupation on Thanet and faunal analysis is on-going. Thus far, three fallow deer specimens have been identified, two of which have been made available for analysis. All of the fallow deer specimens derived from an area situated between the villages of Monkton and Minster (see Bendrey 2003; Morris nd).

Tothill Street, Minster, Isle of Thanet, Kent

Rescue excavations by Museum of London Archaeology (MoLA) in 2010 produced a substantial faunal assemblage from the prehistoric and Roman (late $1^{\text {st }}$ to mid- $3^{\text {rd }}$ century AD) settlement of Tothill Street, Minster, known herein as Minster. Three fallow deer specimens were identified including the palmate surface of an antler.

\section{London sites}

MoLA also recovered two fallow deer bones from Roman occupation layers at sites in Southwark, London. The first was recovered as part of a substantial faunal assemblage from Silvester Street in 1978, probably of $2^{\text {nd }}$ century date (Cowan et al. 2009). The second is thought to come from a mid$1^{\text {st }}-2^{\text {nd }}$ century warehouse on the banks of the Thames, near London Bridge Drummond-Murray and Wills nd).

\section{$\delta^{13} \mathrm{C}, \delta^{15} \mathrm{~N}$ and $\delta^{34} \mathrm{~S}$ Stable Isotopes}


The analysis of $\delta^{13} \mathrm{C}$ and $\delta^{15} \mathrm{~N}$ isotopes in bone collagen represents an established method for reconstructing the diet of humans and animals in the past. The underlying principles of this approach have been explained in detail elsewhere (see Ambrose 1993, 2000; Katzenberg 2000; Lee-Thorp 2008; Sealy 2001) and are therefore only briefly recounted here. At the most basic level, $\delta^{13} \mathrm{C}$ and $\delta^{15} \mathrm{~N}$ isotope ratios reflect a long-term average of the plant carbohydrates and proteins consumed by herbivores. In temperate environments such as Northern Europe, marine resource exploitation is evidenced by high $\delta^{13} \mathrm{C}$ values (e.g. Barrett et al. 2001); although in warmer climates this can also result from the consumption of $C_{4}$ photosynthesising plants (Vogel and Van der Merwe 1977). The $\delta{ }^{15} \mathrm{~N}$ values reflect the proportional contribution of plant and animal dietary protein, with elevated values providing evidence for individuals that feed at a higher trophic level (Ambrose and Norr 1993; Schoeninger et al. 1983). This is a gross oversimplification of the broad range of factors that can cause variation in $\delta^{13} \mathrm{C}$ and $\delta^{15} \mathrm{~N}$ signatures. Although diet is generally considered to have the greatest impact on variability, some of the other wide-ranging variables that affect isotope ratios are discussed below in the context of the new results presented here.

In a number of cases it was possible for us to combine our carbon and nitrogen isotope results with those from sulphur $\left(\delta^{34} \mathrm{~S}\right)$ isotope analysis, the latter undertaken to examine the possibility of marine influences on the diet of some of the animals presented in this study (Craig et al. 2006; Richards et al. 2001, 2003). Marine water has a $\delta^{34} S$ value of $20.3 \%$ (Rees et al. 1978; Richards et al. 2001) and coastal regions, due to the effects of sea spray and marine inundation, may have elevated $\delta^{34} \mathrm{~S}$ soil values, although this trend can be affected by local geological, meteorological and agronomic variables. Animals feeding in areas affected by sea spray can have higher $\delta^{34} S$ values than those sourcing their diets from further inland. For example, island herbivores typically have $\delta^{34} S$ values between $+12 \%$ ond $+17 \%$ o (e.g. Nehlich et al. 2012) and bone collagen $\delta^{34} S$ values above $14 \%$ o have been linked to the sea spray effect (Leach et al. 1996; Richards et al. 2001).

The collagen-extraction protocol followed a modified version of the Longin method (Brown et al. 1998). A fragment of bone weighing between 0.5 and $1.0 \mathrm{~g}$ was sampled from each specimen using a drill with a diamond wheel attachment. The outer cortex of the bone was abraded to remove any adhering contaminants. Each sample was then placed in polypropylene test tubes and demineralised in $10 \mathrm{ml}$ of $0.5 \mathrm{M} \mathrm{HCl}$ at $4^{\circ} \mathrm{C}$. The $\mathrm{HCl}$ was changed approximately every 2 days until demineralisation was complete. Demineralised specimens were thoroughly rinsed in deionised water and then gelatinized in a $\mathrm{pH} 3$ solution of $\mathrm{HCl}$ at $70^{\circ} \mathrm{C}$ for 48 hours. The supernate containing the soluble collagen was collected using an ezee-filter before freeze-drying. $0.6 \mathrm{mg}$ of collagen from each sample was weighed into $3.5 \times 5 \mathrm{~mm}$ tin capsules in duplicate. In addition to the archaeological samples, a modern cattle sample from an individual of known isotope composition was subject to the same extraction process and subsequent analysis in order to identify any procedural problems.

Isotope ratios of carbon, nitrogen and sulphur were measured by continuous flow-elemental analysis-isotope ratio mass spectrometry (CF-EA-IRMS) at the NERC Isotope Geosciences Laboratory facility at Keyworth in Nottinghamshire. The instrumentation comprises an elemental analyser (Flash/EA) coupled to a ThermoFinnigan Delta Plus XL isotope ratio mass spectrometer via a ConFlo III interface. Replicate analysis of well-mixed samples indicated a precision of better than $\pm 0.2 \%$ and samples with a $\mathrm{C} / \mathrm{N}$ ratio of $3.2( \pm 0.3)$ were considered to be sufficiently well preserved to yield 
reliable $\delta^{13} \mathrm{C}$ and $\delta^{15} \mathrm{~N}$ ratios. Collagen carbon, nitrogen and sulphur isotope ratios $\left(\delta^{13} \mathrm{C}, \delta^{15} \mathrm{~N}\right.$ and $\delta^{34} \mathrm{~S}$ ) are reported in per mil (\%) relative to VPDB, AIR and VCDT standards respectively. The $1 \sigma$ reproducibility for mass spectrometry controls in this batch of analysis were $\delta^{15} \mathrm{~N}= \pm 0.12 \%, \delta^{13} \mathrm{C}= \pm$ $0.15 \%$ and $\delta^{34} S= \pm 0.20 \%$. These isotope ratios were calibrated using an in-house reference material M1360 p (powdered gelatine from British Drug Houses) with known values for $\mathrm{C}, \mathrm{N}$ and $\mathrm{S}$ calibration.

\section{Results}

Isotope data for the sites investigated are presented in tables 1-3 and figure 2. Summary statistics for some international sites analysed as part of a wider fallow deer dataset are included in table 3 and figure 2. Where individual results are plotted, the $\delta^{13} \mathrm{C}$ and $\delta^{15} \mathrm{~N}$ values represent a mean of duplicate samples, which were within $0.2 \%$ in all instances. Means and standard deviations for these sites are also presented.

Considering the relatively small number of individual British samples $(n=49)$ from a single species of broadly similar date, analysis produced a broad range of results $\left(-20.0\right.$ to $-23.0 \%$ for $\delta^{13} \mathrm{C}$ and 2.2 to $10.1 \%$ for $\delta^{15} \mathrm{~N}$ ). Caution must be exercised when comparing samples of different size but it appears that the two largest datasets, from Fishbourne and Monkton, can be differentiated by their $\delta^{13} \mathrm{C}$ values. Monkton shows considerably higher values and very little overlap exists, with only one sample from each site plotting within the range for the other. Mann-Whitney tests demonstrated a highly significant difference in $\delta^{13} \mathrm{C}$ values between the two sites $(P=<0.001, M W U=18.0)$. However, $\delta^{15} \mathrm{~N}$ values are similar and show no significant difference $(P=0.937, M W U=133)$.

The two EKAR samples also show substantial variation in carbon values, one plotting well within the range of the Fishbourne samples and the other closer to the Monkton specimens. The three samples from Minster show a high degree of variation, particularly in terms of $\delta^{13} \mathrm{C}$. Sample KT205 has the second highest $\delta^{13} \mathrm{C}$ value of the entire dataset, whereas KT203 has the second lowest of all samples. The other Minster sample (KT204) plots close to the Fishbourne mean, yet surprisingly given the location, none plot amongst the Monkton samples.

The single specimen from Arcadia Buildings, Southwark plots close to the main bulk of Fishbourne samples but the element recovered from nearby London Bridge shows a very different signature, having the lowest $\delta^{13} \mathrm{C}$ and $\delta^{15} \mathrm{~N}$ value in the entire dataset.

Five of the Monkton specimens cluster relatively tightly, all within one standard deviation. The other three samples diverge quite widely but defining meaningful outlying individuals is a difficult and imprecise process in such a small dataset. One sample (-20.0\%) has a considerably higher $\delta^{13} \mathrm{C}$ value than all of the British samples so far studied. Unsurprisingly the larger sample set from Fishbourne shows a greater degree of variation. Most of the divergent samples are notable for their $\delta^{13} \mathrm{C}$, either plotting closer to the Monkton specimens or having particularly low values $(<22.5 \%$ ), although two have very high $\delta^{15} \mathrm{~N}$ values $(9.1 \%$ and $10.1 \%$ ) and are of an order relatively rarely observed in terrestrial herbivores. One antler sample from Fishbourne has very low $\delta^{15} \mathrm{~N}\left(3.8 \%\right.$ ) and higher $\delta^{13} \mathrm{C}$ than any other sample from the site (-20.9\%) (See table 3). 


\begin{tabular}{|c|c|c|c|c|c|}
\hline Site & Element & $\begin{array}{l}\delta^{13} C_{\mathrm{VPBD}} \\
(\%)\end{array}$ & $\begin{array}{l}\delta^{15} N_{\text {AIR }} \\
(\% \circ)\end{array}$ & $C: N$ & $\begin{array}{l}\delta^{34} S_{V C D T} \\
(\%)\end{array}$ \\
\hline Fishbourne & Mandible & -21.9 & 5.4 & 3.3 & \\
\hline Fishbourne & Antler & -21.3 & 6.1 & 3.4 & \\
\hline Fishbourne & Metatarsal & -22.4 & 7.0 & 3.3 & \\
\hline Fishbourne & Metatarsal & -21.8 & 6.7 & 3.4 & \\
\hline Fishbourne & Tibia & -22.5 & 7.0 & 3.3 & \\
\hline Fishbourne & Antler & -21.8 & 5.2 & 3.4 & \\
\hline Fishbourne & Metatarsal & -22.0 & 4.8 & 3.3 & \\
\hline Fishbourne & Metatarsal & -22.4 & 9.1 & 3.3 & 13.2 \\
\hline Fishbourne & Ulna & -22.3 & 6.3 & 3.4 & \\
\hline Fishbourne & Metacarpal & -22.0 & 6.8 & 3.3 & \\
\hline Fishbourne & Metacarpal & -21.5 & 7.3 & 3.3 & \\
\hline Fishbourne & Metacarpal & -21.6 & 8.2 & 3.4 & 12.5 \\
\hline Fishbourne & Antler & -21.6 & 6.5 & 3.3 & \\
\hline Fishbourne & Metapodial & -21.9 & 5.7 & 3.4 & \\
\hline Fishbourne & Metacarpal & -22.7 & 7.2 & 3.3 & \\
\hline Fishbourne & Metacarpal & -22.2 & 6.5 & 3.3 & \\
\hline Fishbourne & Antler & -22.1 & 5.7 & 3.3 & 9.1 \\
\hline Fishbourne & Antler & -21.2 & 5.9 & 3.3 & \\
\hline Fishbourne & Metacarpal & -22.1 & 6.2 & 3.3 & 3.2 \\
\hline Fishbourne & Radius & -22.8 & 10.1 & 3.3 & 14.0 \\
\hline Fishbourne & Femur & -22.8 & 5.8 & 3.4 & \\
\hline Fishbourne & Scapula & -21.8 & 6.5 & 3.4 & \\
\hline Fishbourne & Mandible & -21.7 & 5.3 & 3.4 & \\
\hline Fishbourne & Scapula & -22.1 & 6.8 & 3.4 & \\
\hline Fishbourne & Femur & -22.1 & 5.9 & 3.3 & \\
\hline Fishbourne & Metatarsal & -21.8 & 5.5 & 3.4 & \\
\hline Fishbourne & Metacarpal & -21.7 & 7.5 & 3.4 & \\
\hline Fishbourne & Metacarpal & -21.7 & 5.0 & 3.4 & \\
\hline Fishbourne & Pelvis & -22.2 & 6.9 & 3.3 & 11.6 \\
\hline Fishbourne & Antler & -20.9 & 3.8 & 3.4 & 14.2 \\
\hline Fishbourne & Metacarpal & -22.1 & 6.5 & 3.5 & \\
\hline Fishbourne & Humerus & -22.0 & 6.7 & 3.4 & \\
\hline Fishbourne & Femur & -22.2 & 6.3 & 3.3 & 9.1 \\
\hline Fishbourne & Upper molar & -21.6 & 7.2 & 3.3 & \\
\hline $\begin{array}{l}\text { East Kent } \\
\text { Access Road }\end{array}$ & Antler & -21.2 & 5.7 & 3.4 & 17.3 \\
\hline $\begin{array}{l}\text { East Kent } \\
\text { Access Road }\end{array}$ & Metatarsal & -21.9 & 5.8 & 3.4 & \\
\hline Minster & Antler & -22.9 & 4.3 & 3.4 & 18.0 \\
\hline
\end{tabular}




\begin{tabular}{|l|l|l|l|l|l|}
\cline { 1 - 2 } Minster & Humerus & -22.1 & 6.7 & 3.3 & 12.5 \\
\hline Minster & Tibia & -20.3 & 5.2 & 3.4 & 14.9 \\
\hline $\begin{array}{l}\text { London } \\
\text { Bridge }\end{array}$ & Metatarsal & -23.0 & 2.2 & 3.3 & \\
\cline { 1 - 1 } $\begin{array}{l}\text { Silvester } \\
\text { Street }\end{array}$ & Scapula & -22.2 & 5.6 & 3.3 & \\
\hline Monkton & Metacarpal & -21.8 & 5.5 & 3.2 & \\
\hline Monkton & Metacarpal & -20.7 & 7.3 & 3.3 & \\
\hline Monkton & Antler & -20.0 & 6.2 & 3.3 & \\
\cline { 1 - 2 } Monkton & Scapula & -21.2 & 6.4 & 3.2 & \multirow{2}{*}{8.2} \\
\hline Monkton & Antler & -21.1 & 6.1 & 3.3 & \multirow{2}{*}{8.9} \\
\hline Monkton & Scapula & -20.9 & 5.7 & 3.3 & \\
\hline Monkton & Metatarsal & -21.0 & 6.4 & 3.3 & \\
\hline Monkton & Radius & -21.2 & 8.5 & 3.3 & 8.9 \\
\hline
\end{tabular}

Table $1 \delta^{13} \mathrm{C} \delta^{15} \mathrm{~N}$ and $\delta^{34} \mathrm{~S}$ isotopic values for the Dama specimens

\begin{tabular}{|l|c|c|c|c|c|}
\hline & $\boldsymbol{\delta}^{13} \mathbf{C}$ Mean & $\boldsymbol{\delta}^{13} \mathbf{C} \mathbf{S D}$ & $\boldsymbol{\delta}^{15} \mathbf{N}$ Mean & $\boldsymbol{\delta}^{15} \mathbf{N}$ SD & Number \\
\hline Antler & -21.3 & 0.81 & 5.5 & 0.86 & 10 \\
\hline Postcrania & -21.9 & 0.58 & 6.4 & 1.29 & 38 \\
\hline
\end{tabular}

Table 2 Comparison of mean values for antler specimens and postcranial elements across the dataset

\begin{tabular}{|l|c|c|c|c|c|}
\hline & $\begin{array}{c}\boldsymbol{\delta}^{13} \mathbf{C} \\
\text { Mean }\end{array}$ & $\boldsymbol{\delta}^{\mathbf{1 3}} \mathbf{C ~ S D}$ & $\begin{array}{c}\boldsymbol{\delta}^{15} \mathbf{N} \\
\text { Mean }\end{array}$ & $\boldsymbol{\delta}^{\mathbf{1 5}} \mathbf{N}$ SD & $\mathbf{~ N}$ \\
\hline Fishbourne & -22.0 & 0.44 & 6.5 & 1.18 & 34 \\
\hline Monkton & -21.0 & 0.51 & 6.5 & 0.97 & 8 \\
\hline Minster & -21.8 & 1.35 & 5.4 & 1.21 & 3 \\
\hline EKAR & -21.6 & 0.53 & 5.8 & 0.03 & 2 \\
\hline London Bridge & -23.0 & - & 2.2 & - & 1 \\
\hline Silvester Street & -22.2 & - & 5.6 & - & 1 \\
\hline Mallorca (2 sites) & -20.4 & 0.56 & 5.4 & 0.71 & 52 \\
\hline Turkey (2 sites) & -20.6 & 0.47 & 3.4 & 0.46 & 59 \\
\hline
\end{tabular}

Table 3 Mean $\delta^{13} \mathrm{C}$ and $\delta^{15} \mathrm{~N}$ values for the sites investigated thus far, including the samples from Turkey and Mallorca 


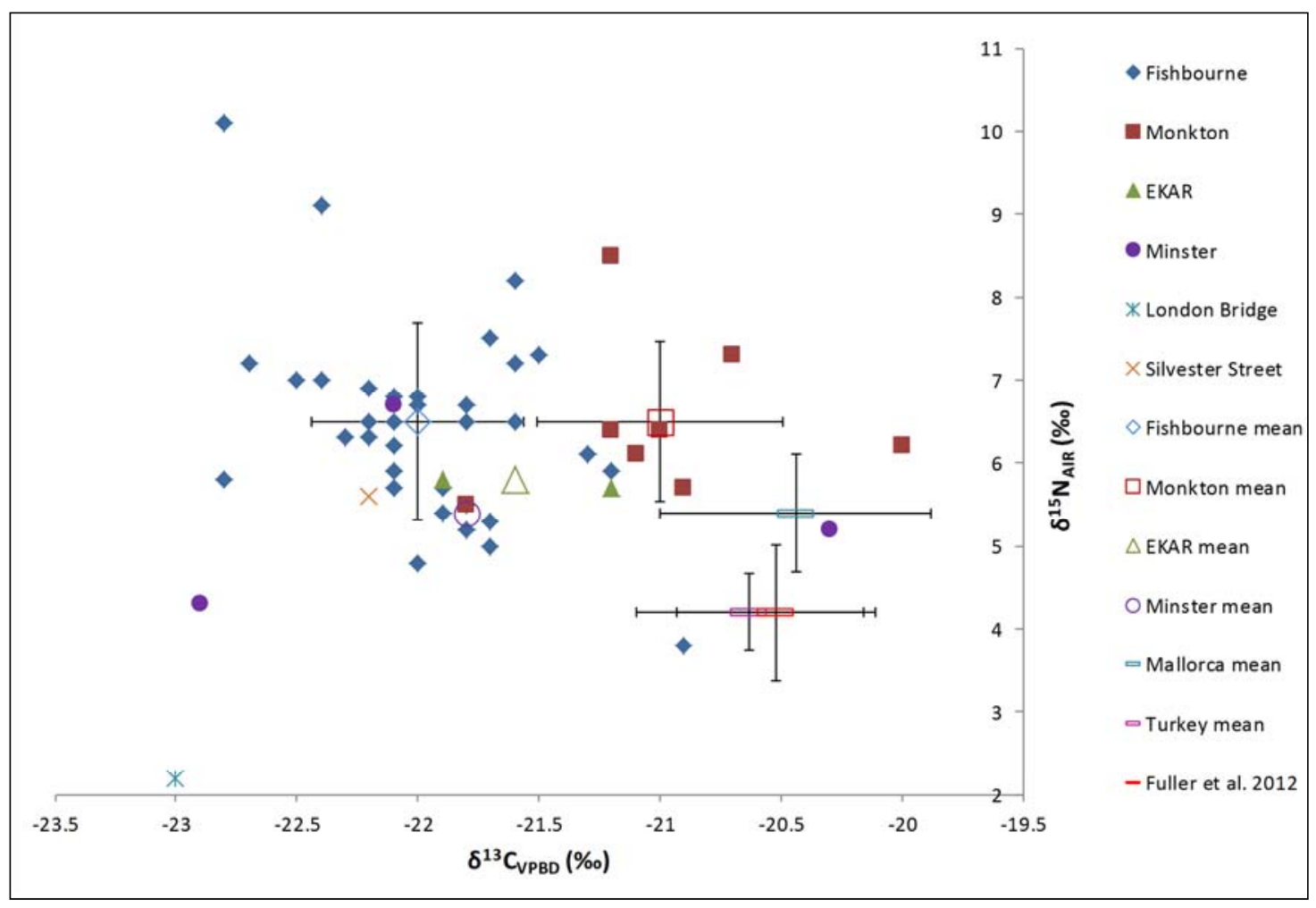

Fig. 2 Isotope results for Roman fallow deer specimens from the UK and summary comparative data from Mallorca and Turkey. Site means and standard deviations are represented by hollow markers and error bars indicate the standard deviation $(1 \sigma)$

\section{Discussion}

This new dataset makes an important contribution to the very limited corpus of isotope data for fallow deer. As the only previously published comparative data for European fallow deer (other than from Monkton which is presented here) are five samples from Turkey (Fuller et al. 2012, see Figure 2) and four which were analysed as part of ${ }^{14} \mathrm{C}$ dating programmes (see Sykes et al. 2011) interpretation of the results is preliminary and tentative at this stage.

It is clear from the dataset that the UK fallow deer are, in general, markedly removed from both the Turkish and Mallorcan individuals. The bulk of the UK samples are more depleted in $\delta^{13} \mathrm{C}$, but have higher $\delta^{15} \mathrm{~N}$ values, although there are individuals that fall outside of these trends. The $\delta^{13} \mathrm{C}$ values from the eastern Mediterranean sites of Neolithic/Bronze Age Bademagaci Hoyuk ( $n=25$, and 5 from Fuller et al. 2012) and Iron Age to Byzantine Sagalassos ( $n=26)$, in south west Turkey and also Roman Pollentia $(n=26)$ and Sa Mesquida $(n=26)$ in Mallorca indicate higher $\delta^{13} C$ values from these climates. This supports the findings of Van Klinken et al. (1994), in which a range of Holocene fauna demonstrated a positive correlation between $\delta^{13} \mathrm{C}$ and rising temperatures. This contrasts with the results of Stevens et al. (2006) who demonstrated $\delta^{15} \mathrm{~N}$ values positively correlated with temperature, with $\delta^{13} \mathrm{C}$ values exhibiting a negative correlation. However, the relationship between climate and isotope values is complex and wide-ranging variables could be responsible for these patterns. 
The general trends in the UK results, in comparison with those from the Mediterranean, suggest that they are broadly indicative of the signature that might be expected for fallow deer living within a northern European environment. The fact that the majority of specimens cluster around the Fishbourne and Monkton deer, populations that we are most confident represent established breeding populations (Sykes et al. 2006; 2011) strengthens this hypothesis and raises the possibility that $\mathrm{C} / \mathrm{N}$ isotopes may be useful for differentiating the remains of animals that lived/died in northern Europe from those that represent body parts imported from the Mediterranean.

Samples from the two Turkish sites cluster closely, having combined means of $-20.6 \%$ for $\delta^{13} \mathrm{C}$ $(S D=0.5)$ and $4.2 \%$ for $\delta^{15} \mathrm{~N}(\mathrm{SD}=0.5)$. These results, as well as those from Mallorca and elsewhere in Europe, will be explored fully as the current programme of research progresses. They are presented here as preliminary comparative datasets only. One outlying sample from Fishbourne plots close to the mean $\delta^{13} \mathrm{C}$ and $\delta^{15} \mathrm{~N}$ of the Turkish samples with higher $\delta^{13} \mathrm{C}(-20.9 \%$ ) and considerably lower $\delta^{15} \mathrm{~N}(3.8 \%)$ than all but one other sample. It is not particularly rare for British herbivores to exhibit such low $\delta^{15} \mathrm{~N}$ values and some studies have provided results of $2 \%$ or less for cattle, horses and roe deer (e.g. Stevens et al. 2010). However, the combination of low $\delta^{15} \mathrm{~N}$ values with comparatively high $\delta^{13} \mathrm{C}$ is rare for British cervids. Although samples for our study are small, results from the other British fallow deer suggest that baseline plant values are unlikely to generate such low $\delta^{15} \mathrm{~N}$ ratios and for this divergent value to be acquired from a British site, the individual is unlikely to have been alive and feeding in Britain for any length of time. Given that fallow deer are not native to northern Europe; it is entirely feasible that this individual was raised in a different environment, such as the eastern Mediterranean, where a combination of environmental factors is more likely to give rise to such isotope values.

This particular Fishbourne outlier is also interesting as it is one of six antler fragments recovered from the site and derived from a post-hole, a deposit that the excavators deemed to be votive (Sykes pers. comm.). Outlying isotope values from antler samples must, however, be treated with caution, as it is a faster developing tissue than bone, meaning that results from the two materials are not directly comparable. During antler development considerable stress is placed on the deer's mineral reserves and 'cyclic reversible osteoporosis' occurs, particularly on non-weight bearing bones (Bubenik 1983). This means that the body draws on its mineral reserves to grow antler, a process of cycling that could potentially cause further fractionation. However, this is considered unlikely to be the cause of the outlying data presented here, as if further fractionation had occurred $\delta^{15} \mathrm{~N}$ values would be higher, whereas the antlers with outlying values from both Minster and Fishbourne have very low $\delta^{15} \mathrm{~N}$ values (4.3\%o and 3.8\%o respectively). In fact the mean $\delta^{15} \mathrm{~N}$ value for antler is lower than in postcrania across the whole dataset (Table 2). Overall inter-element variation is not substantial and other explanations for outlying values must be explored, such as the possibility that the elements were traded from elsewhere.

Carbon and nitrogen isotope analysis represents a poor tool for reconstructing provenance but in this instance it is at least worthy of consideration. Given the evidence for the Roman trade in fallow deer body parts and the significance of antler in particular, it seems possible that this specimen represents a shed antler imported from a region with a warmer climate, the eastern Mediterranean providing a possible candidate. Forthcoming oxygen isotope results have the potential to clarify this possibility. With clear evidence of a breeding population locally, it is interesting that antler might be 
imported from afar to these sites. As yet these specimens have not been ${ }^{14} \mathrm{C}$ dated and acquiring more precise dates is key to the interpretation of these samples. It is possible that the traded antler could predate the first imported generations, as described in Sykes et al. (2006) for Fishbourne. If this proves not to be the case, there are a number of reasons why the curation or acquisition, at some distance, of an otherwise easily sourced resource may be seen as important. However, more research on modern antler from individuals of known life history is required to test the comparability of antler and postcranial samples.

The two samples from the East Kent Access Road have very limited interpretative potential as only three specimens have been recorded from zone 20 of the road scheme. It is perhaps noteworthy that one plots amongst the Fishbourne specimens and the other with the Monkton deer - both assumed to be breeding populations. Given the proximity of Monkton, where evidence for a breeding population is considerably stronger (Sykes et al. 2011) than at the East Kent Access Road site, it is reasonable to assume that these individuals did live on the Isle of Thanet and therefore are a useful extension to the Monkton dataset. On the other hand, three specimens from nearby Minster produced signatures that diverge substantially from those at Monkton. If it is assumed that the sample from Monkton represents locally raised individuals, then it is tempting to suggest that two of the fragments from Minster are not from the area, or at least were not managed as part of the same herd. One sample plots close to the Fishbourne mean, while another, an antler, has relatively low $\delta^{15} \mathrm{~N}$ value and a very low $\delta^{13} \mathrm{C}$ value. This antler differs markedly from all other Kent samples and given the strong evidence for antler trade and the possibility that this is evidenced at Fishbourne, it can again be tentatively suggested that this element may have been brought to the area from elsewhere in the UK or beyond. The extremely low $\delta^{15} \mathrm{~N}$ value for the London Bridge specimen is also noteworthy. However, due to a lack of comparative data, at present this individual can only be highlighted as an interesting outlier and the aetiology of this value is unknown.

There are a number of examples of samples with high $\delta^{15} \mathrm{~N}$ values in this dataset. Three samples from Fishbourne stand out with values of $8.2 \%$ (metacarpal), 9.1\%o (metacarpal) and 10.1\%o (radius) and one from Monkton at $8.5 \%$ (radius) is similarly elevated. All of these elements are large and from individuals of at least sub-adult age and fully weaned prior to death, as care was taken not to sample juvenile material that could preserve the remnants of a nursing signal. The consumption of substantial quantities of animal proteins by adult cervids is implausible, therefore other causes of $\delta^{15} \mathrm{~N}$ variation to explain these elevated $\delta^{15} \mathrm{~N}$ values must be considered. Understanding of the multitude of variables which impact on $\delta^{15} \mathrm{~N}$ signatures remains far from comprehensive (Sponheimer et al. 2003a, 2003b) and consequently equifinality represents a substantial hurdle to interpretation.

Different forms of physiological stress can cause increases in $\delta^{15} \mathrm{~N}$ values, although research demonstrating this link has been on modern individuals and/or on taxa that differ physiologically from fallow deer (e.g. Fuller et al. (2005) morning sickness in pregnant women, Katzenberg and Lovell (1999) pathological bone, Hobson et al. (1993) nutritionally stressed birds and Webb et al. (1998) locusts). This is an attractive theory when considering, at least at Fishbourne, there is evidence of first generation imports, relatively soon after the Roman conquest, to an area with an unfamiliar climate and dietary resources. It is plausible that the animals may have suffered from nutritional stress, perhaps through failing to adapt to the new environment, poorly suited 
management regimes or limited dietary resources, both on the journey and once emparked. However, nutritional stress is still a major cause of cervid mortality even in modern Britain (Stevens, pers. comm.) and is therefore likely to have resulted in death prior to causing a detectable trace in slowly modifying bone collagen.

If these animals are first generation imports, with $\delta^{15} \mathrm{~N}$ results indicative of an area with different plant baseline values to the UK, then early Roman dates would be expected from the forthcoming ${ }^{14} \mathrm{C}$ dating programme. The incorporation of the $\delta^{34} \mathrm{~S}$ results from a number of Fishbourne samples offers an alternative explanation as several are elevated in comparison to other individuals at the same site and from across the UK (Table 1). Analysis of $\delta^{34} S$ values can help to identify marine influences on the diet which result from being managed in close proximity to the coast (Craig et al. 2006, Privat et al. 2007, Richards et al. 2001, 2003). Although Fishbourne is approximately $6 \mathrm{~km}$ from the coast in the modern day, in the Roman period the shore would have been far closer. Seaweed could have been exploited, but this would have also elevated $\delta^{13} \mathrm{C}$ values (Balasse et al. 2005; Mulville et al. 2009) and can therefore be discounted. However, even now the remains of the palace are less than $\mathbf{2 0 0}$ metres away from an area of salt marsh. It seems likely that in antiquity the grounds of the palace may have taken in salt marsh areas, as part of a large 'natural garden' to the south of the villa (Figure 3). Due to the isotope composition of halophytes (plants which favour saline environments), salt marsh grazing generates high $\delta^{15} \mathrm{~N}$ values in bone collagen but has little effect on $\delta^{13} \mathrm{C}$ values (Britton et al. 2008). Salt marsh grazing on a coastal estuary is also likely to have the same effect as sea spray, incorporating oceanic sulphate $\left(\mathrm{SO}_{4}\right)$ that elevates $\delta^{34} \mathrm{~S}$ in the surrounding sediments and plants and thus the grazing animals. Salt marsh sediments can also have higher $\delta^{34} S$ values due to microbial activity and inundation of sea water (Böttcher et al. 1998). Therefore salt marsh grazing provides the most plausible explanation for the outlying $\delta^{15} \mathrm{~N}$ results at Fishbourne. 


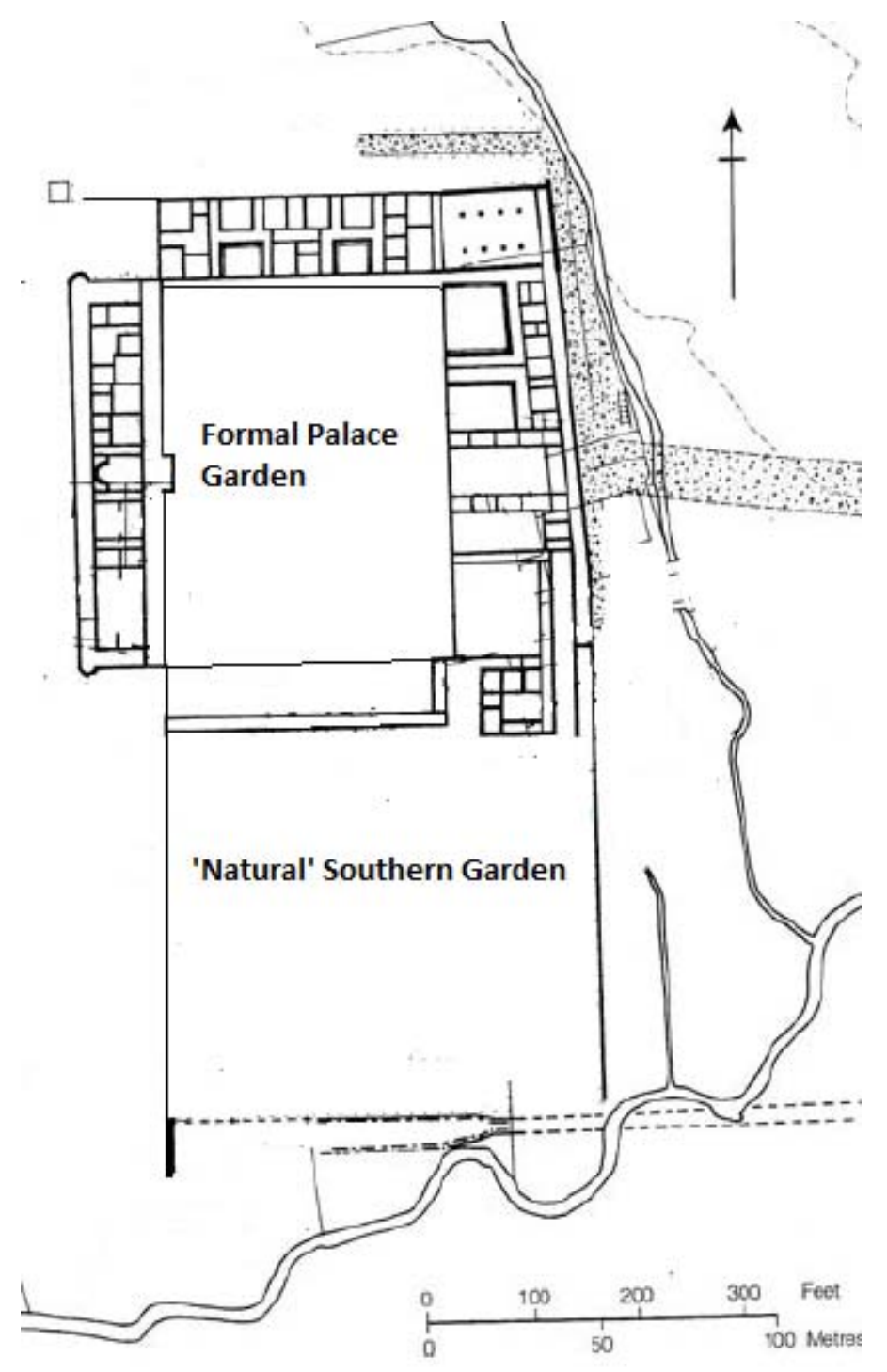

Fig. 3 The extent of the Flavian palace at Fishbourne showing the south garden with some of its associated features (after Cunliffe 1998)

To have achieved such elevated $\delta^{15} \mathrm{~N}$ values, with one individual having a higher value than any from the study by Britton et al. (2008), the fallow deer would have had to have exploited salt marsh resources routinely. The fact that some deer had $\delta^{34} \mathrm{~S}$ and $\delta^{15} \mathrm{~N}$ signatures suggestive of salt marsh grazing whilst others at the same site did not, may indicate that methods of deer management and the location of the palace's deer park may have changed through time. According to the first-century AD author Columella (De Res Rustica, Book IX, I.1):

'Fallow deer serve to enhance the splendour and pleasure of their owners. Those who keep game shut up for their own pleasure are content to construct a park, on any suitable site in the neighbourhood'

It may be that what was considered to be a 'suitable site' at one stage of the occupation of the palace altered either in favour of, or away from salt marsh areas. If this is the case, it should be possible to resolve the chronology of any shifting patterns of deer and landscape management through the forthcoming programme of radiocarbon dating. This study may also elucidate other 
developing management practices where individuals, over time or through other discriminating factors (age, sex, selective breeding) were managed differently and had access to a different range of resources.

As noted previously, there appears to be a clear separation in $\delta^{13} \mathrm{C}$ values between Monkton and Fishbourne. All of the samples are well within the range that can be expected from herbivore species feeding in temperate environments and therefore contributions from $\mathrm{C}_{4}$ plants are not responsible for this division. Samples from other sites included in this discussion, East Kent Access Road and Minster, despite the small sample sizes, do not conform to this separation, with individuals from both sites falling within the two ranges. The British dataset remains small and more results from samples that are currently in process will hopefully elucidate the aetiology of the varied signatures. Monkton samples were analysed at a separate laboratory (ORAU) and are therefore currently being repeated to check for any inter-lab variation.

\section{Conclusion}

This paper represents important progress in the stable isotope investigation of the management of the European fallow deer in Roman Britain. It also serves to introduce a modest European dataset on which future studies can draw and discusses some possible interpretations for signatures that will be expanded and refined as the dataset increases in size.

The wide-ranging results indicate that diverse signatures can be expected for the sub-species. At present equifinality represents a barrier to interpretation but some patterns are beginning to emerge. The integration of evidence from landscape archaeology and classical texts as well as metric data has aided in untangling some problems of interpretation in this paper, but the integration of wider lines of enquiry is needed. Samples of antler from Fishbourne and to a lesser extent Monkton are considered likely to be traded specimens from a warmer climate, possibly the eastern Mediterranean. More samples, currently in process, have the potential to clarify how widespread trade and exchange of antler, perhaps for medicinal purposes, was.

Interpreting the samples with outlying $\delta^{15} \mathrm{~N}$ values is complex and the discussion emphasises the multifarious variables that can be responsible. No single factor can be confidently identified as accounting for all the results but with the integration of the $\delta^{34} S$ results, salt marsh grazing is considered the most likely explanation for individuals with elevated $\delta^{15} \mathrm{~N}$ at Fishbourne. Results are closely comparable to those acquired by Britton et al. (2008) from the salt marsh environment of Brean Down in the Severn Estuary. Also salt marsh was in close proximity during the Roman period and it is likely that Fishbourne's southern garden - an area now presumed to represent a park encompassed the salt marsh to the south of the palace. A comprehensive programme of ${ }^{14} \mathrm{C}$ dating has the potential to elucidate whether chronological shifts in management practices occurred. These interpretations will be refined with the integration of results from further isotope analyses, as well as the on-going genetics research and other lines of enquiry, including morphometrics, porosimetry and/or histological analysis to investigate the health of the animals. Sources of anthropological data also have the potential to provide a fruitful line of evidence.

\section{Acknowledgements}


This research was conducted as part of the Dama International Project, which is funded by the Arts and Humanities Research Council (standard grant no. AH/I026456/1). We are grateful to Rhiannon Stevens for her opinions on the data presented in this paper and to the two anonymous reviewers. Thanks also go to Lena Strid and Rebecca Nicholson for submitting and providing information on the samples from the East Kent Access Road. Data from Monkton, previously published by Sykes et al. (2011) was acquired through a radiocarbon dating project funded by the Oxford Radiocarbon Accelerator Dating Service.

\section{References Cited}

Ambrose SH (1993) Isotopic analysis of paleodiets: Methodological and interpretive considerations. In: Sandford MK (ed) Investigation of ancient human tissue: chemical analyses in anthropology. Gordon and Breach Science Publishers, Langhorne, pp 59-130

Ambrose SH (2000) Controlled diet and climate experiments on nitrogen isotope ratios of rats. In: Ambrose SH, Katzenberg MA (eds) Biogeochemical approaches to palaeodietary analysis. New York: Kluwer Academic/Plenum Publishers, pp 2432-59

Ambrose SH, Norr L (1993) Experimental evidence for the relationship of the carbon isotope ratios of whole diet and dietary protein to those of bone collagen and carbonate. In: Lambert JB, Grupe, G (eds) Prehistoric human bone: archaeology at the molecular level. Springer, New York, pp 1-37

Ballase M, Tresset A, Dobney K, Ambrose SH (2005) The use of isotope ratios to test for seaweed eating in sheep. J. Zool. Soc. Lond. 266:283-291

Barrett JH, Beukens RP, Nicholson RA (2001) Diet and ethnicity during the Viking colonization of Northern Scotland: Evidence from fish bones and stable carbon isotopes. Antiquity 75:145-154

Bendrey R (2003) The identification of fallow deer (Dama dama) remains from Roman Monkton, the Isle of Thanet, Kent. In: Riddler ID (ed) Materials of manufacture: the choice of materials in the working of bone and antler in northern and central Europe during the first millennium AD. British Archaeological Reports, International Series, S1193. Archaeopress, Oxford, pp 15-18

Böttcher ME, Oelschl Sger, Höpner T, Brumsack H, Rullkötter J. (1998) Sulfate reduction related to the early diagenetic degradation of organic matter and 'black spot' formation in tidal sandflats of the Genman Wadden Sea (southern North Sea): Stable isotope $\left({ }^{13} \mathrm{C},{ }^{34} \mathrm{~S},{ }^{18} \mathrm{O}\right)$ and other geochemical results. Org. Geochem. 29:1517-1530.

Britton K, Müldner G, Bell M (2008) Stable isotope evidence for salt marsh grazing in the Bronze Age Severn Estuary, UK: implications for palaeodietary analysis at coastal sites. J. Archaeol. Sci. 35:21112118

Brown TA, Nelson DE, Vogel JS, Southon JR (1988) Improved collagen extraction by modified Longin method. Radiocarbon 30:171-177

Bubenik G (1983) The endocrine regulation of the antler cycle. In: Brown R (ed) Antler development in cervidae. Texas A\& I University, Kingsville, TX, pp 73-107

Carden RF, Hayden TJ (2006) Epiphyseal fusion in the postcranial skeleton as an indicator of age at death of European fallow deer (Dama dama, Linnaeus, 1758). In: Ruscillo D (ed) Recent advances in ageing and sexing animal bones. Oxford, Oxbow, pp 227-236 
Columella LM (ed. \& trans. by ES Forester, EH Heffner) (1955) On agriculture (Loeb Classical Library 361). Heinemann, London

Cowan C, Seeley F, Wardle A, Westman A, Wheeler L (2009) Roman Southwark settlement and economy: excavations in Southwark 1973-91. MOLA Monograph 42. Museum of London, London

Craig OE, Ross R, Andersen SH, Milner N, Bailey GN (2006) Focus: sulphur isotope variation in archaeological marine fauna from northern Europe. J. Archaeol. Sci. 33:1642-1646

Cunliffe B (1971a) Excavations at Fishbourne 1961-1969, Vol. I, The Site (Reports of the Research Committee of the Society of the Antiquaries of London 26). The Society of Antiquaries, Leeds

Cunliffe B (1971b) Excavations at Fishbourne 1961-1969, Vol. I,The finds (Reports of the Research Committee of the Society of the Antiquaries of London 27). The Society of Antiquaries, Leeds

Cunliffe B (1998) Fishbourne Roman palace. Tempus, Stroud

Davies SJM, MacKinnon M (2009) Did the Romans bring fallow deer to Portugal? Environ. Archaeol. $14: 15-26$

DeNiro MJ (1985) Postmortem preservation and alteration of in vivo bone collagen isotope ratios in relation to paleodietary reconstruction. Nature 317:806-809

Drummond-Murray J, Wills O (nd) London Bridge Station Area 8, Station Approach, SE1 (Site Code: LB195). Museum of London Archaeology Service Archive Report (1997-06)

Fuller BT, De Cupere B, Marinova E, Van Neer W, Waelkens M, Richards MP (2012)

Isotopic Reconstruction of Human Diet and Animal Husbandry Practices During the ClassicalHellenistic, Imperial, and Byzantine Periods at Sagalassos, Turkey. Am. J. Phys. Anthropol. 149:157171

Fuller BT, Fuller JL, Sage NE, Harris DA, O'Connell TC, Hedges REM (2005) Nitrogen balance and $\delta^{15} \mathrm{~N}$ : Why you're not what you eat during nutritional stress. Rapid Commun. Mass Spectrom. 19:24972506

Grant A (1971) The animal bones. In B. Cunliffe (ed.) Excavations at Fishbourne 1961-1969. Reports of the Research Committee of the Society of Antiquaries of London no. 27. Society of Antiquaries, London, pp 377-388

Hobson KA, Alisauskas RT, Clark RG (1993) Stable-nitrogen isotope enrichment in avian tissues due to fasting and nutritional stress: implications for isotopic analyses of diet. The Condor 95:388-394

Jones WHS (1963) Pliny Natural History, Volume VIII, Books XXVIII-XXXII, Harvard University Press, London

Katzenberg MA (2000) Stable isotope analysis: A tool for studying past diet, demography, and life history. In: Katzenberg MA, Saunders SR (eds) Biological anthropology of the human skeleton. WileyLiss Publishers, New York, pp. 305-327 
Katzenberg MA, Lovell NC (1999) Stable isotope variation in pathological bone. Int. J. Osteoarchaeol. 9:316-324

Langbein J, Chapman N (2003) Fallow deer. Mammal Society, London

Leach BF, Quinn CJ, Lyon GL (1996) A stochastic approach to the reconstruction of prehistoric human diet in the pacific region from bone isotope signatures. Tuhinga 8:1-54

Lever C (1977) The naturalised animals of the British Isles. Granada Publishing, St. Albans

Lee-Thorp JA (2008) On isotopes and old bones. Archaeometry 50:925-950

Madgwick R, Mulville J, Stevens RE (2012) Isotopic analysis of fauna from British middens of the Late Bronze Age: Evidence for diversity in foddering strategy and herd management. Environ. Archaeol.

Manley J and Rudkin D (2005) Facing the palace: excavations in front of the Roman palace at Fishbourne (Sussex, UK) 1995-99. Sussex Archaeol. Collect. 141

Massetti M (2002) Island of deer: natural history of the fallow deer of Rhodes and the vertebrates of the Dodecanese (Greece). City of Rhodes Environment Organisation, Rhodes

Masseti M, Cavallaro A, Pecchioli, E and Vernesi C (2006) Artificial occurrence of the fallow deer Dama dama dama (L., 1758), on the island of Rhodes (Greece): Insight from mtDNA analysis. Hum. Evol. 21:167-176

Millais JG (1906) Mammals of Great Britain and Ireland. Longman, London

Morris J (nd) Assessment of the animal bone from Tothill Street, Minster, Kent (KT-TSM10). Unpublished Report, Museum of London Archaeology

Mulville J, Madgwick R, Stevens R, O'Connell T, Craig O, Powell A, Sharples N (2009) Isotopic analysis of faunal material from South Uist, Western Isles, Scotland. J. North Atl. 2:51-59

Nehlich O, Fuller, BT, Márquez-Grant N, Richards MP (2012) Investigation of diachronic dietary patterns in the islands of Ibiza and Formentera, Spain: Evidence from sulfur stable isotope ratio analysis. Am. J. Phys. Anthropol. 149:115-124

Privat KL, O'Connell TC, Hedges REM (2007) The distinction between freshwater- and terrestrialbased diets: methodological concerns and archaeological applications of sulphur stable isotope analysis. J. Archaeol. Sci. 34: 1197-1204

Rees CE, Jenkins WJ, Monster J (1978) The sulphure isotopic composition of ocean water sulphate. Geochim. Cosmochim. Acta 42:377-381

Richards MP, Fuller BT, Hedges REM (2001) Sulphur isotopic variation in ancient bone collagen from Europe: implications for human palaeodiet, residence mobility and modern pollutant studies. Earth and Planetary Science Letters. 191: 185-190

Richards MP, Fuller BT, Sponheimer M, Robinson T, Ayliffe L (2003) Sulphur isotopes in palaeodietary studies: a review and results from a controlled feeding experiment. Int. J. Osteoarchaeol. 13:37-45 
Schoeninger MJ, DeNiro MJ, Tauber H (1983) Stable nitrogen isotope ratios of bone collagen reflect marine and terrestrial components of prehistoric human diet. Science 220:1381-1383

Sealy J (2001) Body tissue chemistry and palaeodiet. In: Brothwell DR and Pollard AM (eds) Handbook of archaeological sciences. John Wiley and Sons Publishers, Chichester, pp 269-279

Sponheimer M, Robinson T, Ayliffe L, Roeder B, Hammer J, Passey B, West A, Cerling T, Dearing D, Ehleringer J (2003a) Nitrogen isotopes in mammalian herbivores: hair $\delta^{15} \mathrm{~N}$ values from a controlled feeding study. Int. J. Osteoarchaeol. 13:80-87

Sponheimer M, Robinson TF, Roeder BL, Passey BH, Ayliffe LK, Cerling TE, Dearing MD, Ehleringer JR (2003) An experimental study of nitrogen flux in llamas: Is ${ }^{14} \mathrm{~N}$ preferentially excreted? J. Archaeol. Sci. 30:1649-1655

Stevens RE, Lightfoot E, Hamilton J, Cunliffe B, Hedges REM (2010) Stable isotope investigations of the Danebury hillfort pit burials. Oxf. J.Archaeol 29:407-428

Stevens R, Lister A, Hedges, REM (2006) Predicting diet, trophic level and palaeoecology from bone stable isotope analysis: a comparative study of five red deer populations. Oecologia 149:12-21

Sykes NJ (2004) The introduction of fallow deer to Britain: a zooarchaeological perspective. Environ. Archaeol. 9:75-83

Sykes NJ (2007) Animal bones and animal parks. In: Liddiard, R. (ed) The Medieval deer park: new perspectives. Windgather Press, Macclesfield, pp 49-62

Sykes NJ (2010) Fallow deer. In: TP O'Connor, NJ Sykes (eds) Extinctions and invasions: a social history of British fauna. pp 51-58. Windgather Press, Macclesfield

Sykes NJ, Baker K, Carden RF, Higham TFG, Hoelzel AR, Stevens RE (2011) New evidence for the establishment and management of the European fallow deer (Dama dama dama) in Roman Britain. J. Archaeol. Sci. 38:156-165

Sykes NJ ,Carden RF (2011) Were fallow deer spotted (OE *pohha/*pocca) in Anglo-Saxon England? Reviewing the evidence for Dama dama dama in early medieval Europe. Mediev. Archaeol. 59:139161

Sykes NJ, Carden RF, Harris K (in press) Changes in the size and shape of fallow deer - Evidence for the movement and management of a species. Int. J. Osteoarchaeol.

Sykes NJ, White J, Hayes T, Palmer M 2006. Tracking animals using strontium isotopes in teeth: the role of fallow deer (Dama dama) in Roman Britain. Antiquity 80:1-12

Vogel JC, Van der Merwe NJ (1977) Isotopic evidence for early maize cultivation in New York State. Am. Antiq. 42:238-242

Van Klinken GJ, Van der Plicht J, Hedges REM (1994) Bone 13C/12C ratios reXect (palaeo-) climatic variations. Geophys. Res. Lett. 21:445-448

Webb SC, Hedges REM, Simpson SJ (1998) Diet quality influences the $\mathrm{d}^{13} \mathrm{C}$ and $\mathrm{d}^{15} \mathrm{~N}$ of locusts and their biochemical components. J. Exp. Biol. 201:2903-2911 
Whitehead GK (1972) Deer of the world. Constable, London Yalden D (1999) A history of British mammals. Poyser, London 